\title{
STUDY OF EFFICIENCY OF PEELING MACHINE WITH VARIABLE DECK
}

\author{
Andrey Dmitriev ${ }^{1}$, Bulat Ziganshin ${ }^{1}$, Damir Khaliullin ${ }^{1}$, Alexey Aleshkin ${ }^{2}$ \\ ${ }^{1}$ Kazan State Agrarian University, Russia; ${ }^{2}$ Vyatka State University, Russia \\ avd-work@mail.ru, zigan66@mail.ru,damirtag@mail.ru
}

\begin{abstract}
The most important process that affects the quality of the product obtained during the processing of buckwheat into cereals is peeling - the separation of films (outer shells) from the grain, which is carried out by peeling machines that differ in different ways of affecting the grain and the design of working elements. The Kazan State Agrarian University is working on developing devices with a reversible deck for peeling buckwheat grains. Their practical significance lies in the fact that the use of such devices eliminates the need for preliminary separation of grain into fractions according to geometric dimensions, and also increases the efficiency of grain peeling due to the influence of a complex of balanced forces on it. We consider a new design of a device for peeling buckwheat grain with a variable deck, which differs from existing devices in its compactness, low metal consumption, and low energy costs. To determine the performance indicators of the proposed peeling device, a laboratory prototype was created that allows, by changing the rotation frequency of the blade rotor and deck, to determine the peeling coefficient (a quantitative indicator) and the core integrity coefficient (a qualitative indicator). According to the results of the conducted experiments, the best indicators of peeling efficiency are observed, when peeling buckwheat grain with the moisture content 14 , and $15 \%$ after hydrothermal treatment at the rotor speed varied from 2100 to $2250 \mathrm{~min}^{-1}$ and deck speed - from 950 to $1150 \mathrm{~min}^{-1}$.
\end{abstract}

Keywords: grain, buckwheat, cereals, peeling.

\section{Introduction}

Industrial agriculture is a priority branch of economy, providing food security for any country. The development of the agro-industrial section depends directly on the implementation of recent advances in science and technology of crop and livestock production. Current research in the field of improving agricultural machinery is based on fundamental investigations on the interaction of working elements of agricultural machinery with material (grain, soil, plant, etc.), taking into account theoretical developments in related fields of science [1-4].

At present, the processing and production of grain are often imperfect due to the low efficiency of farming machinery and other equipment, which leads to economic losses associated with the inferior quality product [5-8]. This fact applies, in particular, to the processing of buckwheat grain. The use of existing industrial equipment does not allow efficient producing high-quality buckwheat cereals without loss. The necessity of such production is dictated by a low purchase price of buckwheat for processing enterprises, which receive the primary income from the sale of finished cereals. It is well known that the final cost of buckwheat increases several times compared to the purchase price for the manufacturer. It is possible to reduce the final cost by processing buckwheat in the plant farm using adaptive technologies and equipment.

One of the primary operations of cereal production is grain peeling, which means the separation of films (outer shells) from granules. Modern grain peeling machines (peelers), used in industrial production, do not meet the requirements of the manufacturer. Thus, a new design of a grain peeling machine with a variable deck and an original hopper is proposed, which allows intensifying the peeling process and ensure the high quality of the finished product $[9 ; 10]$. At the same time, this peeler has high efficiency of operation for agricultural producers. The device under study was developed on the basis of an analysis of modern devices for grain peeling and theoretical surveys of grain interaction with working elements [11-17].

\section{Materials and methods}

In accordance with previous studies [18-20], three key parameters that affect peeling efficiency were identified:

1. moisture content of the grain $W, \%$;

2. rotor speed $n^{R}, \min ^{-1}$;

3. $\quad$ deck speed $n^{D}, \min ^{-1}$. 
A prototype of a new device with the variable deck for peeling buckwheat grain was developed to determine these parameters (Fig. 1,2).

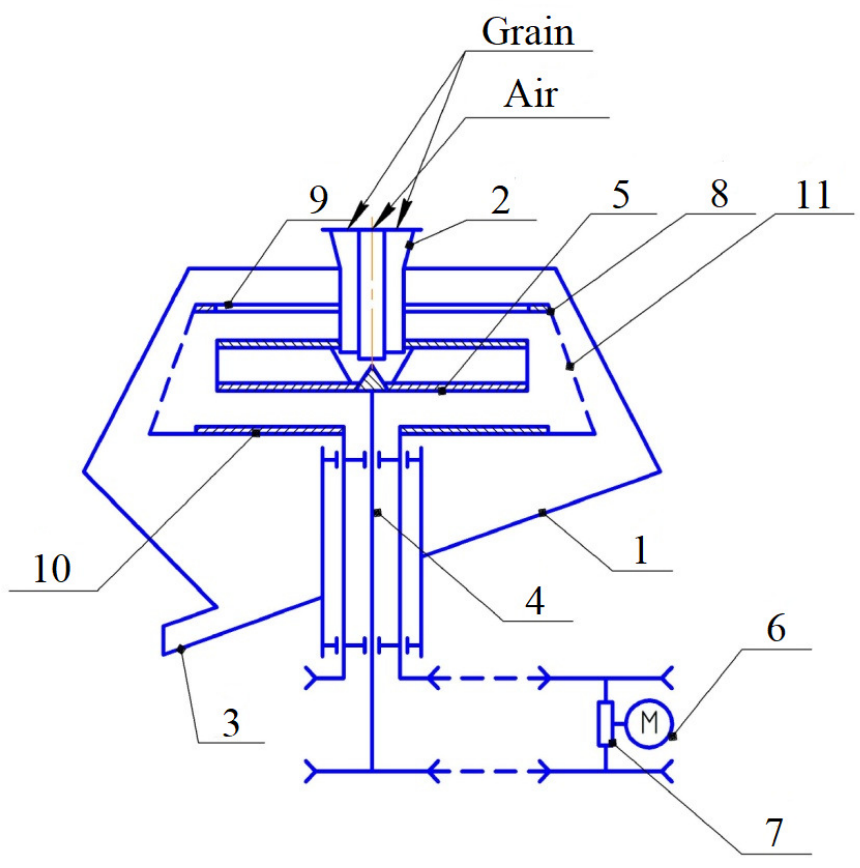

Fig. 1. Scheme of the buckwheat peeling machine with the variable deck: 1 - casing;

2 - hopper; 3 - discharger; 4 - vertical shaft; 5 - blade rotor; 6 -drive; 7 - reversible variator;

8 - deck; 9 - top of the deck; 10 - bottom of the deck; 11 - metal gauze

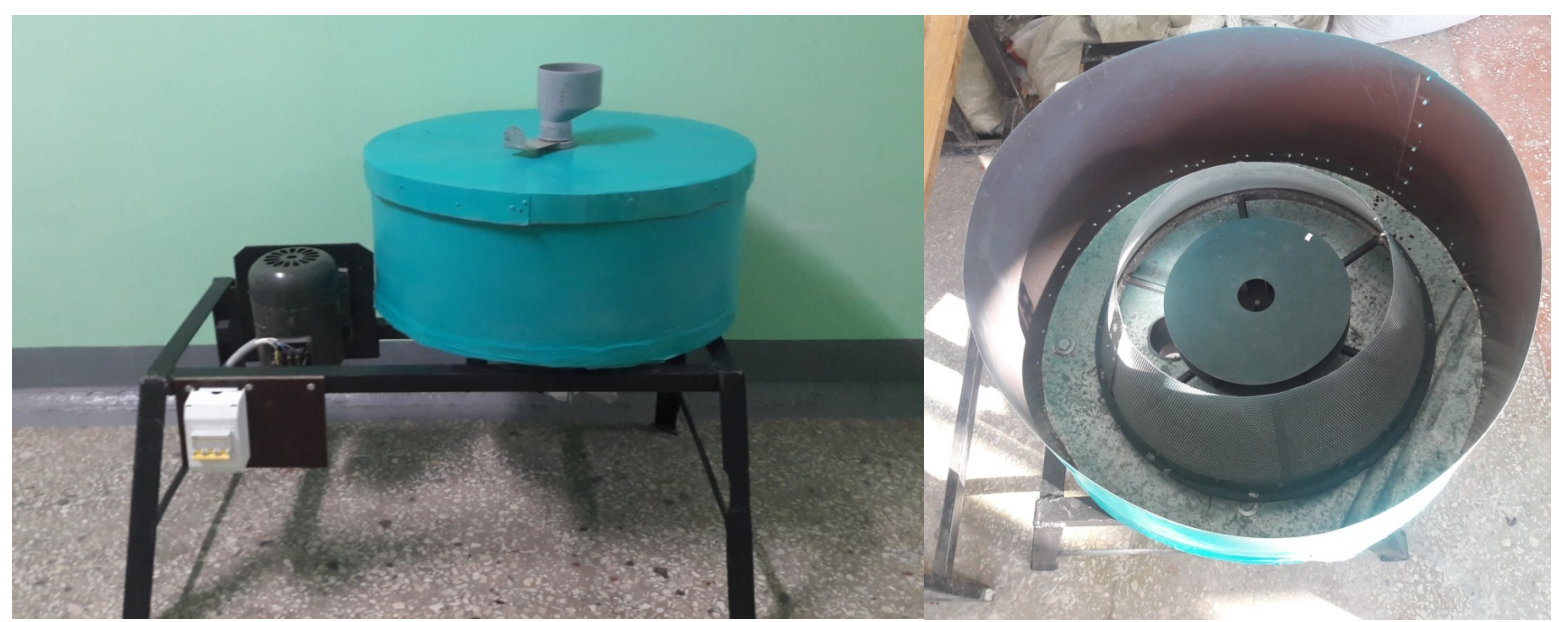

Fig. 2. General view of the peeling machine with the variable deck

The peeler consists of a casing with a discharger, therein a blade rotor mounted on a vertical shaft, a drive and a reversible variator, and the side surface of the rotary deck has the shape of a truncated cone made of a metal gauze with a hole diameter smaller than an equivalent diameter of the grain. The coefficient of the free area (the ratio of the mesh hole area to the total area of the side surface of the deck) is 0.7 . The peeler hopper is an outer pipe with a diameter $d$ and an inner pipe with a diameter $d / 3$, besides, both pipes are coaxially connected by bridges. This design of the hopper provides the material feed to the device through the outer pipe, while air freely enters the working zone of the blade rotor through the inner pipe.

The operation principle of the device is as follows. As mentioned above, the grain is fed through the outer pipe, and air flows into the working zone via the inner pipe. Further, the obtained air-grain mixture is accelerated by the blade rotor, leaves it, and hits the side surface of the rotating deck. The peeling process is carried out due to the impact of each grain with the deck, as well as particle interaction between each other in the air-grain mixture. Grain films (outer shells) are removed from 
the device through the discharger. An additional airflow entering through the inner pipe ensures fast motion of the air-grain mixture and withdrawal of products from the device. Besides, it is used for further separation of the product into fractions.

For the experiments, $150 \mathrm{~g}$ samples of "Kama" buckwheat grains were taken, which were subjected to preliminary hydrothermal treatment and had the moisture content of 14,15 , and $16 \%$ (after cooling). The buckwheat grain had the hoodness of 22-23\% and size uniformity of 97-98\%.

Efficiency was determined after processing in the buckwheat grain peeling machine with the variable deck according to the following parameters:

- rotor diameter - $300 \mathrm{~mm}$;

- rotor height $-50 \mathrm{~mm}$;

- distance between the blade rotor and the deck - $95 \mathrm{~mm}$;

- motor power $-1.1 \mathrm{~kW}$.

There are two indicators in evaluating the peeling efficiency: the peeling coefficient and the core integrity coefficient. The first indicator $K_{p}$ takes into account the quantitative side of the peeling and shows the relative number of the shelled grains. The second indicator $K_{c}$ considers the qualitative side of the process and indicates the relative yield of the obtained product.

\section{Results and discussion}

The experimental results of efficiency determination of peeling buckwheat grains using the developed device are shown in Table 1.

Working characteristics of the grain peeler

Table 1

\begin{tabular}{|c|c|c|c|c|c|}
\hline No. & $\begin{array}{c}\text { Moisture } \\
\text { content, } \\
W, \%\end{array}$ & $\begin{array}{l}\text { Blade rotor speed, } \\
\qquad n^{R}, \min ^{-1}\end{array}$ & $\begin{array}{c}\text { Deck speed, } \\
n^{D}, \min ^{-1}\end{array}$ & $\begin{array}{c}\text { Peeling } \\
\text { coefficient, } \\
K_{p}\end{array}$ & $\begin{array}{l}\text { Core integrity } \\
\text { coefficient, } K_{c}\end{array}$ \\
\hline 1 & \multirow{5}{*}{14} & 1500 & 750 & 0.576 & 0.430 \\
\hline 2 & & 1750 & 875 & 0.704 & 0.534 \\
\hline 3 & & 2000 & 1000 & 0.764 & 0.606 \\
\hline 4 & & 2250 & 1125 & 0.820 & 0.596 \\
\hline 5 & & 2500 & 1250 & 0.780 & 0.534 \\
\hline 6 & \multirow{5}{*}{15} & 1500 & 750 & 0.680 & 0.474 \\
\hline 7 & & 1750 & 875 & 0.718 & 0.548 \\
\hline 8 & & 2000 & 1000 & 0.790 & 0.630 \\
\hline 9 & & 2250 & 1125 & 0.848 & 0.590 \\
\hline 10 & & 2500 & 1250 & 0.812 & 0.542 \\
\hline 11 & \multirow{5}{*}{16} & 1500 & 750 & 0.580 & 0.454 \\
\hline 12 & & 1750 & 875 & 0.650 & 0.540 \\
\hline 13 & & 2000 & 1000 & 0.746 & 0.646 \\
\hline 14 & & 2250 & 1125 & 0.812 & 0.644 \\
\hline 15 & & 2500 & 1250 & 0.772 & 0.530 \\
\hline
\end{tabular}

From the obtained results after statistical processing, the graphical dependencies were sketched (Fig. 3, 4). They show the influence of the rotor and deck speed on the peeling coefficient and core integrity coefficient.

From the analysis of the graph in Fig. 3, it can be determined that with an increase in the speed of the rotor, the peeling coefficient grows for the different moisture contents of the grain. So, the peeling coefficient reaches a maximum, when the moisture content of buckwheat is $14 \%$, and the minimum $K_{p}$ occurs at $W=16 \%$. Moreover, when processing buckwheat grain with the moisture content of 14 and $15 \%$, the maximum efficiency of peeling is achieved at the rotation speed above $2100 \mathrm{~min}^{-1}$. 


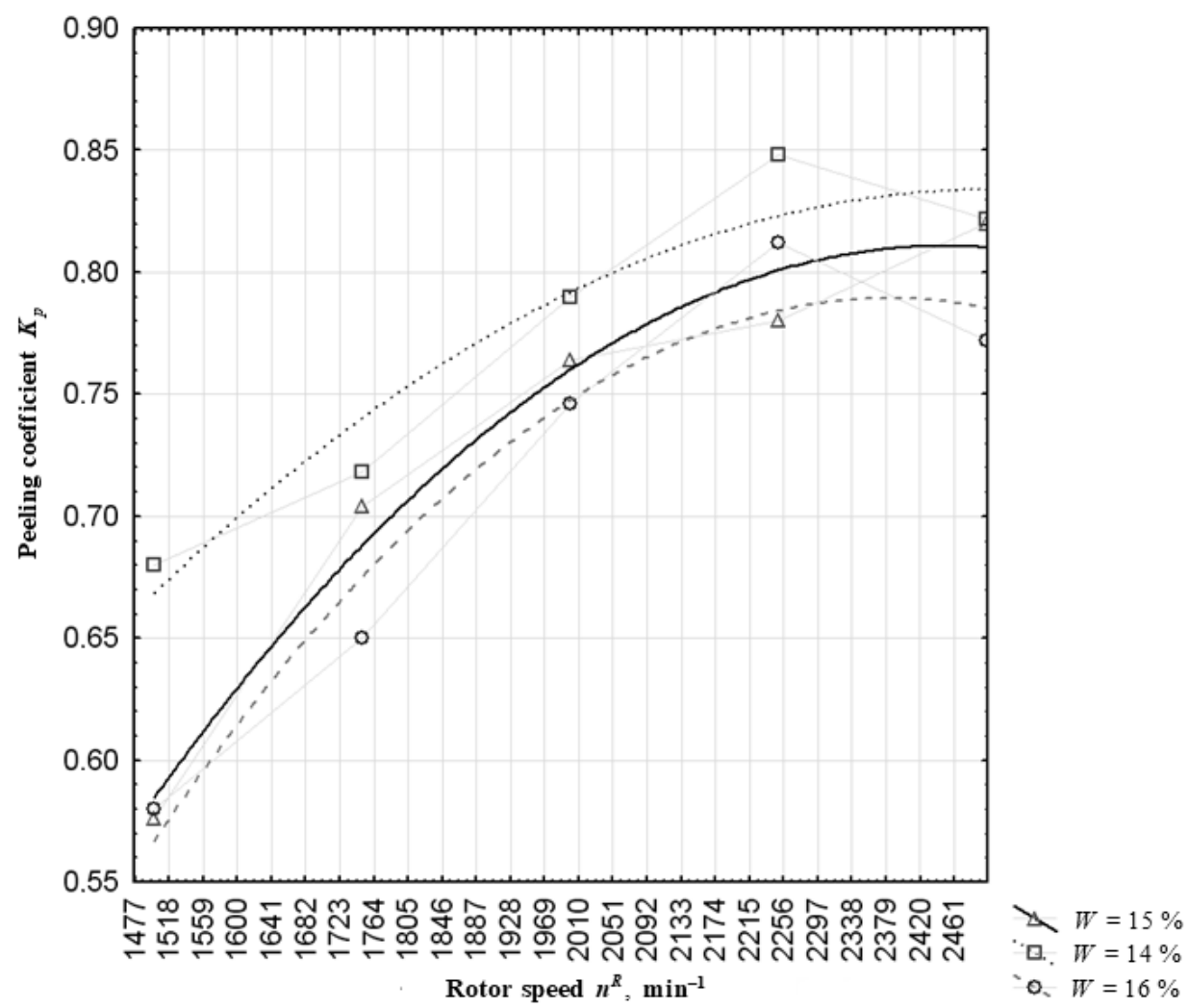

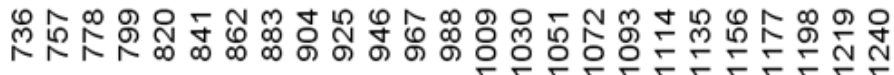

Deck speed $n^{D}, \min ^{-1}$

Fig. 3. Dependence of the peeling coefficient on the rotor and deck rotation speed

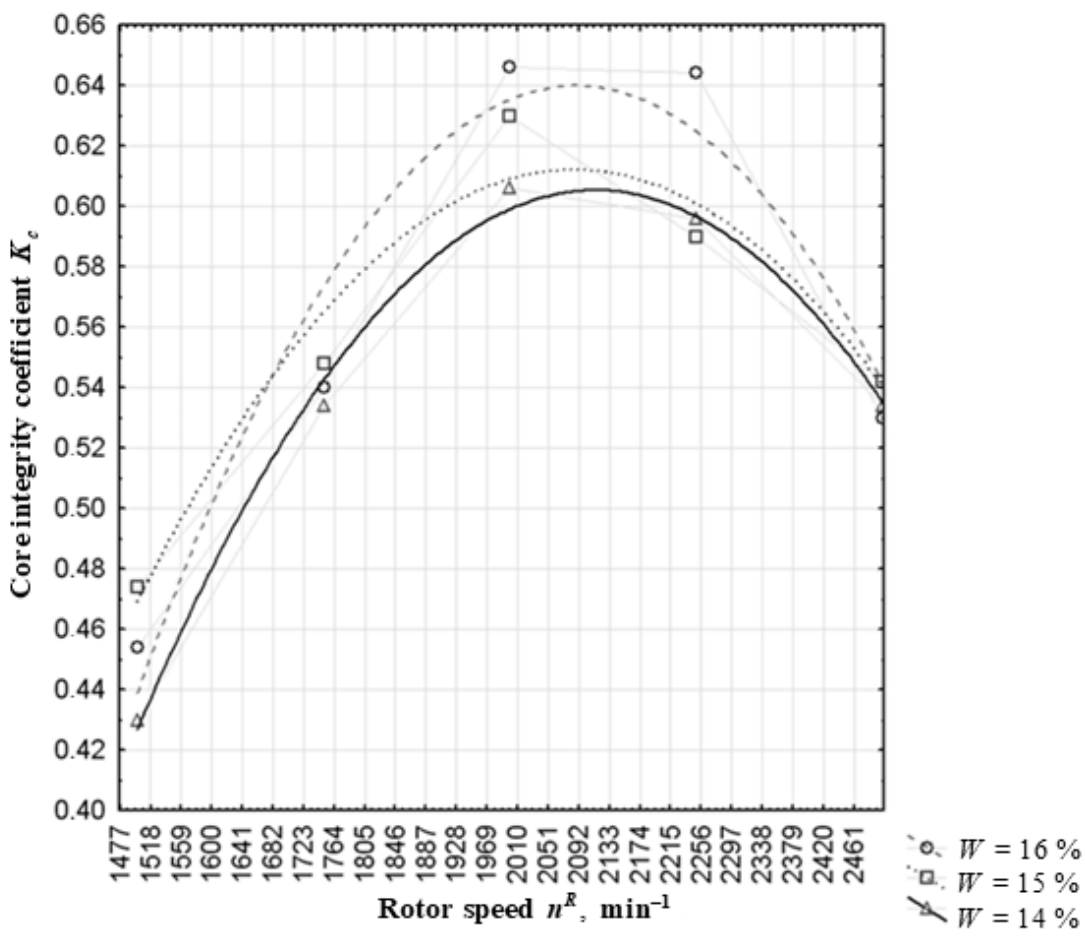

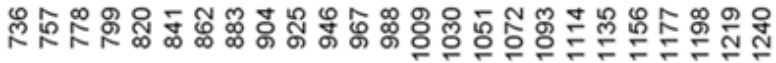

Deck speed $n^{D}, \min ^{-1}$

Fig. 4. Dependence of the core integrity coefficient on the rotor and deck rotation speed 
According to Fig. 4, the core integrity coefficient is reduced as rotor speed increases more than $2100 \mathrm{~min}^{-1}$. This fact can be explained by an increase in the impact of the grain on the working surfaces of the peeling machine. Therefore, in order to achieve the high quality of the peeling process, it is proposed to maintain the rotor speed in the range from 1900 to $2100 \mathrm{~min}^{-1}$.

\section{Conclusions}

1. The best peeling efficiency is observed, when processing buckwheat grain with the moisture content of 14, and $15 \%$ after preliminary hydrothermal treatment at the rotor speed varied from 1900 to $2100 \mathrm{~min}^{-1}$ and the deck rotation speed - from 950 to $1050 \mathrm{~min}^{-1}$.

2. Rational parameters of the developed machine for peeling buckwheat grain with the variable deck are the following: rotor diameter $-300 \mathrm{~mm}$, rotor height $-50 \mathrm{~mm}$, distance between the blade rotor and the deck $-95 \mathrm{~mm}$.

\section{References}

[1] Belinsky A., Ziganshin B., Valiev A., Haliullin D., Galiev I., Adigamov N., Theoretical investigation of increasing efficiency of combine harvester operation on slopes Engineering for Rural Development 18, 2019, Jelgava, Latvia, pp. 206-213. DOI: 10.22616/ERDev2019.18.N252.

[2] Seomushkin N.I., Ziganshin B.G., Yakhin S.M., Gayfullin B.A., Vlasov R.E. Mathematical model of interaction of seeds with the internal surface of sowing block of seed drill in Science, Technology and Higher Education. Strategic Studies Institute, 2012, Westwood, Canada, pp. 531535.

[3] Губайдуллин Д.А., Федяев В.Л., Моренко И.В. Неизотермическое обтекание дисперсными средами вращающихся тел (Non-Isothermal Flow Around Rotating Bodies by Disperse Media) Physical-Chemical Kinetics in Gas Dynamics, vol. 16(3), 2015, pp. 69-79. (In Russian).

[4] Valiev A., Mukhametshin I., Muhamadyarov F., Yarullin F., Pikmullin G. Theoretical substantiation of parameters of rotary subsoil loosener. 18th International Scientific Conference Engineering For Rural Development Proceedings, Vol. 18 May 22-24, 2019, Jelgava, Latvia, pp. $312-318$.

[5] Mudarisov S., Khasanov E., Rakhimov Z. etc. Specifying Two-Phase Flow in Modeling Pneumatic Systems Performance of Farm Machines. Journal of Mechanical Engineering Research and Developments, vol. 40(4), 2017, pp. 706-715.

[6] Mudarisov S.G., Badretdinov I.D., Rakhimov Z.S. etc. Numerical simulation of two-phase "airseed" flow in the distribution system of the grain seeder. Computers and Electronics in Agriculture, vol. 168, 2020, pp.105151.

[7] Khafizov R.N., Khafizov K.A, Nurmiev A.A., Galiev I.G. Optimization of main parameters of tractor and unit for seeding cereal crops with regards to their impact on crop productivity. 17th International Scientific Conference "Engineering for rural development Proceedings", Vol. 17, May 23-25, 2018, Jelgava, Latvia, pp. 168-175.

[8] Galiev I.G., Khafizov K.A, Adigamov N.R., Khusainov R.K. Increase of efficiency of tractors use in agricultural production. 17th International Scientific Conference "Engineering for Rural Development" Proceedings, Vol. 17, May 23-25, 2018, Jelgava, Latvia, pp. 373-377.

[9] Ravil Ibyatov, Andrey Dmitriev, Bulat Ziganshin, Damir Khaliullin and Alsu Zinnatullina. Mathematical modeling of the grain trajectory in the workspace of the sheller with rotating decks. International Scientific-Practical Conference "Agriculture and Food Security: Technology, Innovation, Markets, Human Resources” (FIES 2019). BIO Web Conf. Vol.17, 00093, 2020. DOI: https://doi.org/10.1051/bioconf/20201700093.

[10]Халиуллин Д.Т., Нуруллин Э.Г. Исследование движения зерна в конфузоре пневмомеханического обрушивателя семян подсолнечника (Research of grain movement in confusor pneumo-mechanical destruction of sunflower seeds) Bulletin of Kazan State Agrarian University, 2010, vol. 5.4(18), pp. 122-124 (In Russian).

[11] Kotov D.N., Isaev Yu.M., Kryuchin N.P. etc. Determination of speed of movement of the particle on the rotating cone with shovels. Int. J. Mech. Eng. Technol., 2019, vol. 10(2), pp. 1507-1514.

[12] Kholpanov L.P., Ibyatov R.I. Mathematical modeling of the dispersed phase dynamics Theoretical Foundations of Chemical Engineering, 2005, vol. 39(2), pp. 190-199. 
[13]Нигматулин Р.И. Динамика многофазных сред. Ч.1 (Dynamics of multiphase media. Part 1 . Moscow: Nauka, 1987. 464 p. (In Russian).

[14] Can. J. Pfant Sci. A dehuller for buckwheat samples. Canadian journal of plant science, vol. 65, July 1985, pp. 771-773.

[15]Chandan Solanki, etc. Buckwheat Dehuller and Optimization of Dehulling Parameters. Int.J.Curr.Microbiol.App.Sci., 2018, vol. 7(11): pp. 1041-1052.

[16] Mar'in V.A., Vereshchagin A.L. Physical principles of processing off-grade buckwheat. Foods and Raw Materials, 2016, vol. 4(1), pp. 51-60.

[17] Kabir A.A., Fedele O.K. A Review of Shelling, Threshing, De-Hulling and Decorticating Machines. J Agri Res, 2018, vol. 3(1), 000148.

[18]Дмитриев А.В., Нуруллин Э.Г. Теоретическое определение энергии шелушения на пневмомеханических шелушителях зерна (Theoretical determination of the desiccant energy on the basis of pneumomechanical grain silencers) Bulletin of Kazan State Agrarian University, 2011, vol. 6.1(19), pp. 101-102. (In Russian).

[19]Ибятов Р.И., Дмитриев А.В., Лотфуллин Р.Ш. Исследование движения зерна в рабочем пространстве пневмомеханического шелушителя (Grains movement research in the working space of pneumomechanical silencer) Technics and equipment, 2018, vol. 2, pp. 18-21. (In Russian).

[20]Нуруллин Э.Г. Пневмомеханические шелушители зерна (теория, конструкция, расчет) (Pneumomechanical silencers of grain (theory, construction, calculation)). Kazan: 2011. 308 p. (In Russian). 